\title{
CHARACTERIZATION AND EVALUATION OF SELECTED KAOLIN CLAY DEPOSITS IN NIGERIA FOR FURNACE LINING APPLICATION
}

\author{
J. B. Mokwa ${ }^{1}$, S. A. Lawal', ${ }^{2}$, M. S. Abolarin ${ }^{3}$ and K. C. Bala ${ }^{4}$ \\ $\mathbf{1 , 2 , 3 , 4}$, DePARTMENT OF MeCHANICAL EngineERING, FEDERAL UnIVERSITY OF TECHNOLOGy MinNA - NIGERIA \\ E-mail addresses; ${ }^{1}$ jamesbabamokwa72@gmail.com, 2 lawalsunday@futminna.edu.ng, \\ 3 msabolarin@gmail.com, ${ }^{4}$ katsina.bala@futminna.edu.ng
}

\begin{abstract}
Kaolin and ball clay samples from four states in Nigeria were examined with the aim of determining their chemical composition as well as testing for their suitability as refractory materials for furnaces lining applications. Three kaolin samples were taken from Ikpeshi in Edo, Kasadi in Kebbi and Alaasan in Osun state, while the ball clay sample used as the binder was taken from Badeggi in Niger state. The kaolin samples were tested and beneficiated in other to improve on their alumina contents after which they were characterized and produced as a refractory brick by mixing each kaolin sample with the ball clay in 70:30 ratio. They were then tested comprehensively for the following refractory properties such as: firing shrinkage, apparent porosity, bulk density, cold crushing strength, thermal shock resistance, refractory under load (RUL), thermal expansion, thermal conductivity, $X$-ray diffraction and scanning electron microscope. The results were compared with standard refractory properties for fireclay bricks. The values obtained from the three clay samples $(A, B, C)$ which are from Ikpeshi in Edo, Kasadi in Kebbi and Alaasan in Osun state respectively were within the recommended values for fireclay bricks, most especially sample $C$ which has a refractoriness under load (RUL) of $1348^{\circ} \mathrm{C}$ which is the temperature at which the bricks will collapse under a constant load of $0.2 \mathrm{~N} / \mathrm{mm}^{2}$. This compared favourably with the RUL of other countries in the world.
\end{abstract}

Keywords: Porosity, clay, brick, refractoriness, kaolin

\section{INTRODUCTION}

The pressing needs in Nigeria and the availability of abundant natural resources demand that the direction of utilization of locally available resources be upgraded through scientific and technological insight and new or improved technology to meet the needs of iron and steel industries. Technological development in Nigeria has created awareness and has increased the standard of living of both urban and rural dwellers, leading to increasing use of modern industrial appliances. If Nigeria is to sustain increased industrial growth, the iron and steel industries must be sustained and new one established. These industries make use of furnaces and these furnaces are lined with refractory bricks produced using kaolin or other clays which are presently imported.

\footnotetext{
* Corresponding author, tel: +234-803-599- 5230
}

Refractories belong to the class of ceramic materials which are employed for high temperature applications, usually above $1100^{\circ} \mathrm{C}$ [3]. Refractory materials are used in linings for furnaces, kiln, incinerators, and reactors. They are also used to make crucibles and moulds for casting glass and metals and for surfacing flame detector systems for rocket launch structures [1].

Kaolin are used as fire bricks because of its unique properties such as natural whiteness, fine particle size, non-abrasiveness and chemical stability, in addition to the general properties mentioned above, it is soft and has low viscosity at high solid contents [2].

Kaolin is the main source of alumina in the manufacture of fireclay refractories among other industrial minerals. The higher the alumina content of a kaolin, the higher the refractoriness. Raw materials 
are thus classified to be of high refractory value as the amount of alumina in them increases.

Ball clays are generally used in varying proportions as a binder with kaolin in fire bricks production. The clay being highly plastic, facilitates the forming process and contributes to the dry-strength, or green strength, of the product.

Most research work carried out on refractories in Nigeria had centred on testing for their physical and chemical properties to ascertain their suitability in productions of fire bricks for lining furnaces. There is not much systematic and detailed work carried out on the refractoriness under load of these clays (RUL), which indicates the temperatures at which the clays will collapse under a constant load. This particular research intends to utilize available raw materials kaolin and ball at generating a strong refractory fire bricks material that will withstand high temperature before failing under load.

\section{MATERIALS AND METHOD}

\subsection{Materials}

The following samples of clays were sourced from four states in Nigeria which are Ikpeshi (Akoko Edo) in Edo State, Kasadi Village in Kebbi State, Alasan (Iwoye Juction) in Osun State and Badeggi in Niger State. The clay samples deposit sites were dug two meters deep into the earth using an iron digger and samples were collected at different locations as shown in Table 1. As can be seen from the Table, kaolin is used as the principal raw material while ball clay was used as the binder. The kaolin and ball clay were mixed in suitable proportion of 70:30 ratio in the production of the fire clay bricks. $25 \mathrm{~kg}$ of the clay samples from each state were collected. These samples were subjected to test and based on the outcome of the results, were beneficiated. The beneficiation process involved washing of the clay, sieving, drying and subjecting each sample to gravity separation other beneficiation method used included screening of the kaolin samples at 120 mesh size and froth floatation, this method was employed in reducing the silica content, so as to improve on the alumina level. As well as demagnetizing the samples through a magnetic separator to see the possibilities of reducing the iron content and other impurities like $\mathrm{CaO}, \mathrm{MgO}, \mathrm{Na}_{2} \mathrm{O}_{3}$, $\mathrm{CaCO}_{3}$, and $\mathrm{TiO}_{2}$ (rutile). The samples were also leached using oxalic acid so as to improve on the whiteness, after which the beneficiated kaolin samples were characterized for their chemical, physical properties, refractoriness under load (RUL), SEM and $\mathrm{X}$ - ray diffraction.

\section{2 Methods}

All the experiments for this work were carried out at National Geo-Survey Institute (NGIS) Barnawa, Kaduna, Kaduna Polytechnic, Kaduna and Katsina State University, Katsina. The beneficiated kaolin and ball clay samples were crushed, sieved, pre-treat, mixed in suitable proportion ratio of 70:30, mould, dried before firing in an electric furnace up to $1300^{\circ} \mathrm{C}$. Firing of the brick sample was done gradually at the rate of $5^{\circ} \mathrm{C} /$ minute. The sample was then soaked at $1300^{\circ} \mathrm{C}$ for 2 hours and allowed to cool gradually in the furnace over- night.

\subsection{Chemical Analysis}

The chemical analysis of the raw clay samples was carried out using Atomic Absorption Spectrophotometer (AAS) and X-ray fluorescence (XRF). The percentage composition of the various constituents was recorded on Table 2

\subsection{Refractory Properties}

\subsubsection{Bulk Density}

The bulk density of a refractory body is represented by the weight per unit volume including pore space.

The test pieces were prepared from the clay samples. The specimen was dried in an oven for 24 hours at $110^{\circ} \mathrm{C}$. The dried weight $\left(\mathrm{W}_{\mathrm{d}}\right)$ of the specimen was recorded, after which they were fired in a furnace at $1100^{\circ} \mathrm{C}$. The specimens were then placed in a beaker of water in vacuum desiccators and evacuated completely until bubbling ceased. At this point the airs in the samples have been displaced by water. The specimens were then dried and the soaked weight (Ws) was recorded.

Table 1: Samples used for investigation

\begin{tabular}{cccc}
\hline S/N & Samples & Type of Clay & Location \\
\hline 1 & A & Kaolin & Ikpeshi (Akoko Edo) in Edo State \\
2 & B & Kaolin & Kasadi Village in Kebbi State \\
3 & Kaolin & Ball Clay & Alasan (Iwoye Juction) in Osun State \\
4 & D & Badeggi in Niger State \\
\hline
\end{tabular}


The specimens were then suspended in a beaker of water one after the other and the suspended weight (Wp) was recorded. The average bulk density was calculated from the following expression.

$$
\text { Bulk density }=\frac{W_{d}}{W_{s}-W_{p}} P W
$$

\subsubsection{Moisture Content}

$50 \mathrm{~g}$ of the mixture was weighed out with $0.01 \mathrm{~g}$ accuracy, spread in a thin layer on a sand glass and dried at temperature $110^{\circ} \mathrm{C}$ to constant weight, it was then cooled in a desiccators and re-weighed. The difference in weight was expressed as a percentage to the dry weight as follows:

$$
M C=\frac{G_{W}-G D}{G D} \times 100 \%
$$

Where $M C=$ moisture content, $\mathrm{G}_{\mathrm{w}}=$ mass of the wet sample, $G_{D}=$ mass of the sample after drying.

\subsubsection{Firing Shrinkages}

Firing Shrinkage represents the permanent change that the refractory shapes undergo during heating or re-heating under a given set of condition. The test pieces were dried in an oven at $110^{\circ} \mathrm{C}$ for 24 hours and slowly fired up to $1100^{\circ} \mathrm{C}$ in a muffle furnace at $700^{\circ} \mathrm{C}$ and at subsequent $100^{\circ} \mathrm{C}$ interval. The fired shrinkage (FS) was then calculated using the following expression:

$$
F S=\frac{\text { Change in Length }}{\text { Original Length }} \times 100=\frac{\Delta L}{L} \times 100
$$

\subsubsection{Water Absorption}

The percentage of water absorption determines the rate at which water is been absorbed. This property is important because, it indicates the quantity of moisture which the clay can absorb without collapsing [3].

The test specimens made from the clay samples were dried in an oven till a constant weight was obtained. The samples were then submerged in a boiling water one after the other in such a way that they did not touch the bottom of the vessel. The evaporated water was then replaced by boiling water, and after a boiling period of 4 hours the vessel was cooled to about $25^{\circ} \mathrm{C}$. After removing the adhering water from the samples with moist cloth, the specimens were then weighed again. The dried weight and the soaked weight were measured and recorded [5]. The percentage water absorption was calculated using the formula:

$$
W A=\frac{S W-D W}{D W} \times 100 \%
$$

Where: SW = Soaked Weight; DW = Dried Weight and WA $=$ Water Absorption

\subsubsection{Thermal Shock Resistance}

Thermal Shock Resistance" is a measure of the resistance of a refractory to sudden changes in temperature [4]. Test specimens each of size $50 \mathrm{~mm}$ in diameter and $50 \mathrm{~mm}$ in length were made from the clay samples. They were then inserted into the furnace, which was maintained for $24 \mathrm{hrs}$ at a temperature of $900^{\circ} \mathrm{C}$. The specimens were left in the furnace for 10 minutes and then taken out to cool in a stream of air and then put back into the furnace, which was kept at $900^{\circ} \mathrm{C}$ for another 10 minutes. This process was continued until the test specimens were in such a condition that, after cooling, they can be readily pulled apart; but failure is not deemed to have occurred until the test piece breaks into two equal pieces (parts). The number of complete cycles required to cause failure in each specimen was recorded.

\subsubsection{Apparent Porosity}

Porosity is a measure of volume of all pores present in a material [5]. The test specimens measuring $2.5 \mathrm{~cm}$ $\times 2.5 \mathrm{~cm} \times 2 \mathrm{~cm}$ was cut from a burnt refractory brick by a cut off wheel from within its core and cleaned from dust. The specimens were then dried in an oven at $110^{\circ} \mathrm{C}$ for 24 hours to ensure total water loss, and later fired up to $1100^{\circ} \mathrm{C}$ in a muffle furnace. The dried weights were measured and recorded. The dried specimens were then suspended in distilled water such that the specimen does not touch the bottom or sides of the container. The specimens were later boiled for two hours while still suspended in water, cooled to room temperature and their weights noted. The specimens were then removed from water and water is wiped off from its surface by lightly blotting with a wet towel and weighed in air (W) [1] .

The apparent porosity $(p)$ was then calculated by:

$$
P=\frac{V_{1} \times 100}{V}
$$

Where $\mathrm{V} 1=$ Actual volume of open pores of the specimen $(c c)=(W-D) ; V=$ External volume of the specimen $=(\mathrm{W}-\mathrm{S})$

This can be expressed as:

$$
\text { Apparent porosity }=\frac{W-D}{W-S} \times 100 \%
$$


Where: $\mathrm{W}=$ soaked weight; $\mathrm{D}=$ Dry weight; $\mathrm{S}=$ Suspended weight

\subsubsection{Specific Gravity}

Specific gravity is the ratio of density of the material to density of water. The Powdered clay sample, passed through 100 sieve B.S.S, was introduced using a glass funnel into a previously weighed specific gravity (SG) bottle $\left(W_{P}\right)$, and weighed, $(W)$. The powder sample was covered with distilled water under vacuum and the bottle suspended in water of a known temperature for approximately 15 minutes to equilibrate followed by weighing, $\left(W_{2}\right)$. The bottle was then washed, filled with distilled water and allowed to equilibrate for another 15 minutes and weighed, $\left(W_{1}\right)$. The specific gravity was then calculated based on the following expression:

$$
S G=\frac{W-W_{P}}{\left(W-W_{P}\right)-\left(W_{2}-W_{1}\right)}
$$

where S.G. = Specific gravity; $W_{P}=$ Weight of bottle ; $\mathrm{w}_{1}=$ weight of bottle + water ; $\mathrm{w}=$ weight of picrometer bottle + sample; $w_{2}=$ weight of sample + bottle $+\mathrm{H}_{2} \mathrm{O}$ after boiling.

\subsubsection{Refractoriness}

Refractoriness could be defined as the measure of fusibility of a material and indicates the temperature at which the material softens [6]. Test cone(s) were prepared from each clay specimen, dried and fixed with cement at the centre of a refractory plaque along with pyrometric cones equivalent (PCE) both cones were placed in the furnace in accordance with the American society of Testing Materials (ASTM). The heating rate over the last $200^{\circ} \mathrm{C}$ below the estimated fusion temperature was care- fully controlled at $10^{\circ} \mathrm{C}$ per minute and was observed by the use of an optical pyrometer. The heating continued till the tip of the test cone bent touching the refractory plaque. The plaque bearing the test cone was removed from the furnace and the test cone examined when cold. Refractoriness of the test cone was determined by the temperature equivalent on the standard cone that bent to a large extent similar to the test cone.

\subsubsection{Refractoriness under load}

Refractoriness under load (RUL) is a measure of the deformation behavior of refractory ceramic products subjected to a constant load, at an increasing temperature [7]. A cylindrical test piece normally 50 $\mathrm{mm}$ diameter by $50 \mathrm{~mm}$ height is subjected to a specified compressive load and heated at a specified rate of temperature increase until a prescribe deformation or subsidence occurs, the deformation of the test piece was then recorded. The refractoriness under load of the three beneficiated samples were determined by using an instrument known as RUL/CIC 421 (BSI:1893) 2007 standard. RUL/CIC 421 runs under proteus software on windows it comprises of every information that were needed in carrying out the measurement and evaluating the result data.

\subsubsection{Cold Crushing Strength}

This is the load at which cracks appear in the specimen. The test specimens were cut from refractory shapes preserving the original surface as far as possible. The cold crushing strength of the refractory bricks were carried out by placing the test specimens on a flat surface followed by the application of a uniform load to it through a hydraulic compression testing machine. The load at which cracks appear in the refractory specimen represents the CCS of the specimens.

Cold crushing strength was then calculated using this formula:

$$
\text { C.C.S }=\frac{\text { Length }}{\text { Area }}
$$

\subsubsection{Grain Size Analysis}

Grain Size Analysis is the diameter of individual grains of sediment [1]. The particle size distributions of the samples were determined using the B.S Standard test sieves. $300 \mathrm{~g}$ kaolin clay sample was weighed and poured into already arranged sieves on a mechanical shaker. It was shaken for 25 minutes after which mass on each sieve was determined. The percentage retained (PR) and percentage passing for each sieve and pan was calculated using the following expressions.

$$
P R=\frac{\text { weigth retained }(W R)}{\text { initial weigth }(W I)} \times 100
$$

\subsubsection{X-ray diffraction}

Chemically clays are defined by crystal structure and chemical composition. The X-ray diffraction (XRD) patterns were achieved using a Bruker D8 Advance machine. The pattern were scanned in series of angles diffraction from $10^{\circ}$ to $80^{\circ}(2 \theta)$ in steps of $0.034^{\prime \prime}$ designed for clay using copper (CuKa) with a wavelength of $1.5406 \AA$ as X-ray source. At various angle, the intensity diffracted were measured and 
recorded instantly on a chart, the suited $(\theta)$ and (d) values were generated and received.

\subsubsection{Scanning Electron Microscope}

This is a type of electron microscope that produces images of a sample by scanning it with a focused beam of electrons. The electrons interact with atoms in the sample, producing various signals that contain information about the samples surface topography and composition [8]. The results of the scanning electron microscope of the clay samples are shown in plate 1-4

\subsubsection{Thermal Expansion.}

1. Sample was mounted in the expansion base of the thermal conductivity/expansion meter.

2. The length ( $L$ ) of the sample was measured at room temperature by measuring from the inner edge of the sample on one end, to the inner edge of the angle bracket at the other end.

3. This was recorded with initial expansion of $0 \mathrm{~mm}$.

4. The heater was switch on and with every $50^{\circ} \mathrm{C}$ raise in temperature the increment in length $(L)$ was taken using infrared meter in millimeter.

A Temperature Thermal expansion ( $\mathrm{mm}$ ) curve was then plotted to show the trend as the increment occurred up to the stage in which decrement was noticed due to total removal of moisture and any other impurity. Stated mathematically:

$$
\propto=\frac{\Delta L}{(L \Delta T)}
$$

Where $\propto$ is a constant called coefficient of expansion $\left({ }^{\circ} \mathrm{C}^{-1}\right)[2]$.

\section{RESULTS AND DISCUSSION}

\subsection{Chemical Properties}

The results of the chemical properties tests are presented in Table 2.

From Table 2, the result of the beneficiated sample for $A, B, C$ and $D$ respectively are Alumina $\left(\mathrm{Al}_{2} \mathrm{O}_{3}\right)$;
$30.67 \%, 26.88 \%, 33.10 \%$, and $25 \%$, samples $A, B, C$ and $D$ fall below the standard values range of between 45-65\% for fire clays but compared favourably with that of Auchi, Warri, Eket, Nsu, Malete, Mokwa, Ijero Ekiti, Maraba- Rido and Kankara, all of which are $27.10 \%, 31.10 \%, 28 \%, 31.225,29.8 \%, 28.6 \%$, $30.33 \%, 33.10 \%, 31.82 \%$ [9] While the silica contents for the beneficiated samples $A, B$ and $D$ fall below the internationally acceptable standard for fire clay of between $25-45 \%$, sample C is slightly higher than the maximum international standard of $45 \%$ however they compare favourably with that of Auchi, Warri, Asaba, Uyo, Ozubulu, Nnewi, Nsukka, Enugu, Ijerro Ekiti, Maikunkele, Kaura which are: $57.00 \%$, $55.90 \%$ ， 51.70\%， 54.01\%，59.93\%， 55.12\%， $55.00 \%, 56.30 \%, 51.71 \%$ and $51.68 \%$ respectively. The iron oxide $\left(\mathrm{Fe}_{2} \mathrm{O}_{3}\right)$ value for beneficiated sample C is $0.435 \%$ which fall slightly below the standard value for India fire clay of between $2-5 \%$ while sample $A$ and $B$ falls within the standard acceptable value of $0.5-2.5 \%$, for fire clay. Sample D content value is still above the standard value for fire clay. Other impurities like $\mathrm{CaO}, \mathrm{TiO}_{2}, \mathrm{MnO}, \mathrm{MgO}$, and $\mathrm{ZrO}_{2}$ were reduced to minima, while others are not detected on the beneficiated samples.

\subsection{Physical properties of the kaolin and ball clay samples}

The physical properties obtained from average of five (5) readings from this investigation are shown in Table 3. The explanations of each of the refractory property are made in the following subsections.

\subsubsection{Bulk Density}

From Table 3, the bulk density value of sample A and $C$ were found to compare well with the international acceptable range of $1.7-2.1 \mathrm{~g} / \mathrm{cm}^{2}[1]$. However, the bulk density value for sample $B$ is slightly higher than the normal international acceptable ranges.

Table 2: Chemical analysis of the researched clay samples

\begin{tabular}{ccccccccccccc}
\hline Location & $\mathrm{SiO}_{2}$ & $\mathrm{Al}_{2} \mathrm{O}_{3}$ & $\mathrm{Fe}_{2} \mathrm{O}_{3}$ & $\mathrm{CaO}$ & $\mathrm{MgO}$ & $\mathrm{Na}_{2} \mathrm{O}$ & $\mathrm{K}_{2} \mathrm{O}$ & $\mathrm{MnO}$ & $\mathrm{TiO}_{2}$ & $\mathrm{P}_{2} \mathrm{O}_{5}$ & $\mathrm{ZrO}_{2}$ & $\mathrm{~L} . \mathrm{O} . \mathrm{I}$ \\
\hline Sample A & 53.18 & 30.67 & 0.934 & 0.23 & 0.16 & 0.020 & 0.013 & 0.011 & 2.01 & $<0.001$ & $\mathrm{ND}$ & 11.95 \\
Sample B & 57.41 & 26.88 & 2.432 & 0.09 & 0.01 & $\mathrm{ND}$ & $<0.001$ & 0.04 & 2.81 & $<0.001$ & 0.217 & 8.00 \\
Sample C & 49.30 & 33.10 & 0.435 & 0.10 & 0.04 & 0.025 & 0.06 & 0.15 & 0.02 & $<0.001$ & $\mathrm{ND}$ & 15.64 \\
Sample D & 60.5 & 25 & 5.90 & 0.47 & 0.16 & 0.12 & 1.75 & - & 2.07 & - & - & - \\
\hline
\end{tabular}


Table 3: Physical properties of the three samples investigated

\begin{tabular}{lccc}
\hline \multirow{2}{*}{ Physical Properties } & \multicolumn{3}{c}{ Samples } \\
\cline { 2 - 4 } & $\mathrm{A}$ & $\mathrm{B}$ & $\mathrm{C}$ \\
\hline Bulk Density $\left(\mathrm{g} / \mathrm{cm}^{3}\right)$ & 2 & 2.28 & 1.77 \\
Apparent Porosity $(\%)$ & 21.86 & 10.94 & 21.64 \\
Moisture Content $(\%)$ & 14.00 & 12.00 & 13.33 \\
Water Absorption $(\%)$ & 1.6 & 3.8 & 3.6 \\
Thermal Shock Resistance at $1350^{\circ} \mathrm{C}$ & $28^{+}$ & $20^{+}$ & $23^{+}$ \\
Specific Gravity & 2.37 & 2.41 & 246 \\
Shrinkage $(\%)$ & 1 & 8.5 & 8 \\
Refractoriness $\left({ }^{\circ} \mathrm{C}\right)$ & 1500 & 1420 & 1510 \\
CC Strength $\left(\mathrm{Kg} / \mathrm{cm}^{2}\right)$ & 308.33 & 50.34 & 198.83 \\
\hline
\end{tabular}

\subsubsection{Apparent Porosity}

Table 3, shows the apparent porosity of the three (3) kaolin clay samples. From the table, sample A and C values compared favourably with the apparent porosity values of $21.7 \%$ and $21.8 \%$ for Bomo and Kauranda in Kaduna State respectively and equally close to the $22-25 \%$ for imported fire clay. This values also falls within the required apparent porosity range of refractories, which lies between $20-30 \%$ [6]. While sample $B$ fall below the standard values for fire clay.

\subsubsection{Moisture Contents}

The moisture content were found to be $14 \%$ for sample $A, 12 \%$ for sample $B$ and $13.33 \%$ for sample C. Sample $C$ value are nearly the same as the $13 \%$ value of Zungeru clay [3].

\subsubsection{Water Absorption}

From Table 3, the water absorption was found to be $1.6 \%$ for sample $A, 3.8 \%$ for sample $B$ and $3.6 \%$ for sample $C$. This shows that the three samples can be used as refractory bricks. A brick with water absorption of less than $7 \%$ provides better resistance to damage by freezing [1].

\subsubsection{Thermal Shock Resistance}

From the above results, the thermal shock resistance of all the samples at a temperature of $1200^{\circ} \mathrm{C}, 1250^{\circ} \mathrm{C}$ and $1350^{\circ} \mathrm{C}$ are found to be :- $28^{+}$cycles for sample A. $20^{+}$cycles for sample $B$ and $23^{+}$cycles for sample C. The result for sample $A, B$ and $C$ compared favourably with the internationally acceptable range of between 20-30 cycle for fire clay production [3].

\subsubsection{Specific gravity}

The specific gravity values compare very well with those of some Nigerian clays such as Kpakungu which has a specific gravity value of 2.810 and Maitunbi which has a specific gravity value of 2.836 [3]. The investigated specific gravity values equally compared favourable with the international acceptable range of between $2.0-2.8$.

\subsubsection{Firing shrinkage}

Refractory materials were noted to shrink while in use at high temperature. Results for the fired shrinkage are presented in Table 3 Some changes were noted in the shrinking, at temperature of $1100^{\circ} \mathrm{C}$. At this temperature sample $A$ shrank by $1 \%$, sample $B$ by $8.5 \%$, sample $C$ by $8 \%$. Sample $B$ and $C$ satisfy the standard contents range of $7-10 \%$ values for fired clay [1].

\subsubsection{Refractoriness}

The result in Table 3 showed that the refractoriness of the sample occurred at a temperature of $1500^{\circ} \mathrm{C}$, $1420^{\circ} \mathrm{C}$ and $1510^{\circ} \mathrm{C}$. This high temperature might have been due to the appreciable amount of the alumina content in the clay. The alumina in the clay was a strong indicator of its refractoriness and the higher the alumina, the higher the refractoriness [3]. The refractoriness of the bricks produced shows that the materials could be used for the making of fire bricks. However only sample $A$ and sample $C$. met the minimum international standard of refractory, bricks of between $1500-1700^{\circ} \mathrm{C}$ [6].

\subsubsection{Cold Crushing strength}

From Table 3 above, it was noted that, none of the samples were within the acceptable minimum standard of $1500 \mathrm{~kg} / \mathrm{cm}^{2}$ [3]. Sample A is the strongest and sample $B$ is the weakest. This shows that sample A material will resist much abrasion and will be less attacked by slag, followed by sample $\mathrm{C}$. 


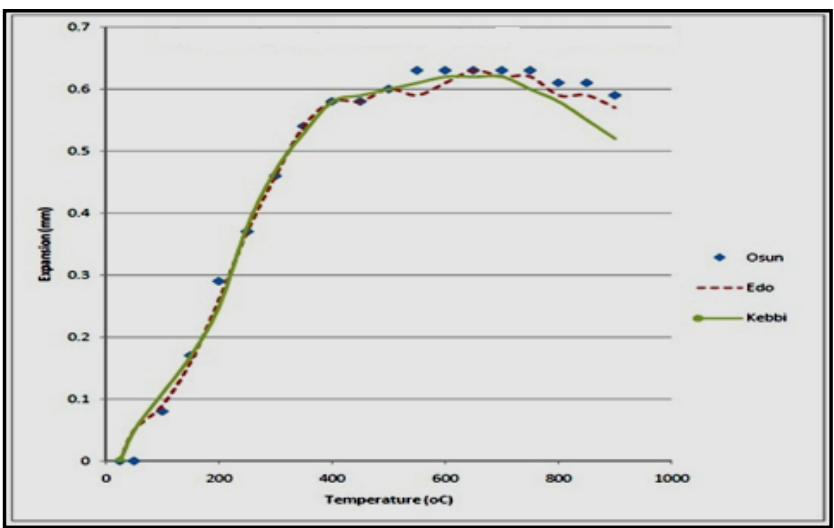

Fig. 1 Thermal Expansion Curves of the Clay Samples

\subsubsection{Thermal Expansion}

Figure 1 shows the thermal expansion of samples from Ikpeshi (sample A), Kasadi (sample B) and Alaassan (sample $\mathrm{C}$ ). At temperature $25^{\circ} \mathrm{C}$ the expansion of the three (3) clay samples are: $0.00 \mathrm{~mm}$. While at temperature $750^{\circ} \mathrm{C}$, the thermal expansion of sample $A, B$ and $C$ are $0.62 \mathrm{~mm}, 0.60 \mathrm{~mm}$ and $0.63 \mathrm{~mm}$ respectively, the maximum value was attained at $750^{\circ} \mathrm{C}$. As the temperature rises to $800^{\circ} \mathrm{C}$ the clay fluxes begin to melt and the clay starts to contract at a rate largely dependent on the flux content. At $800^{\circ} \mathrm{C}$, sample $A$. $B$ and $C$ contract to $0.59 \mathrm{~mm} .0 .58 \mathrm{~mm}$ and 0.61 , The test is normally stopped at $1000^{\circ} \mathrm{C}$ to avoid devitrification of silica tube, at $1000^{\circ} \mathrm{C}$ the three (3) clay samples A.B and $C$ contract to $0.54,0.52$ and 0.52 respectively. From the results it shows that the clay samples are good for the production of refractory bricks.

\subsubsection{Thermal Conductivity}

Table 4 shows the values of the thermal conductivity test for all samples. The values showed that sample $C$ had the least thermal conductivity value of $0.87 \mathrm{~W} / \mathrm{mK}$.
While the highest value was sample $B$ which as a value of $1.11 \mathrm{~W} / \mathrm{mK}$.

Table 4: Thermal conductivity result of the samples

\begin{tabular}{cccc}
\hline Sample & $\begin{array}{c}\text { Temperature 1 } \\
\left({ }^{\circ} \mathrm{C}\right)\end{array}$ & $\begin{array}{c}\text { Temperature 2 } \\
\left({ }^{\circ} \mathrm{C}\right)\end{array}$ & $\begin{array}{c}\text { Thermal } \\
\text { Conductivity }(\mathrm{K})\end{array}$ \\
\hline $\mathrm{A}$ & 48 & 41 & 0.95 \\
$\mathrm{~B}$ & 50 & 40 & 1.11 \\
$\mathrm{C}$ & 51 & 40 & 0.87 \\
\hline
\end{tabular}

\subsubsection{Particle size distribution}

The result of the sieve Analysis carried out on the clay samples revealed that $98.8 \%$. and $97.12 \%$ of samples A and B (Kaolin) and D (Ball clay) used as binder, respectively pass through 75 micron this compared favourably with the standard passing value of $90 \%$ [5]. Sample C (Kaolin) passing value of 86.44 was slightly below the standard value. Based on these results. Sample A, B and D are quite adequate for refractory bricks production.

\subsubsection{X-Ray Diffractions (XRD)}

The X-ray diffraction scan for kaolin clay sample $A$, sample $B$ and sample $C$, shows that the minerals are predominantly composed of kaolinite with some few percentage of quartz, anatase, magnetise and illite as shown in Figure 2-4. The analysis revealed that kaolinite has the highest relative amount of minerals present in the clay sample. Based on the outcome of this analysis the clay tested is a kaolin clay. While figure 5 shows that the clay mineral in Baddegi is composed of quartz with some few amounts of kaolinite, illite and rutile. The analysis revealed that quartz has the highest relative amount of minerals present in the clay sample. Based on the outcome of the analysis the clay tested is a ball clay.

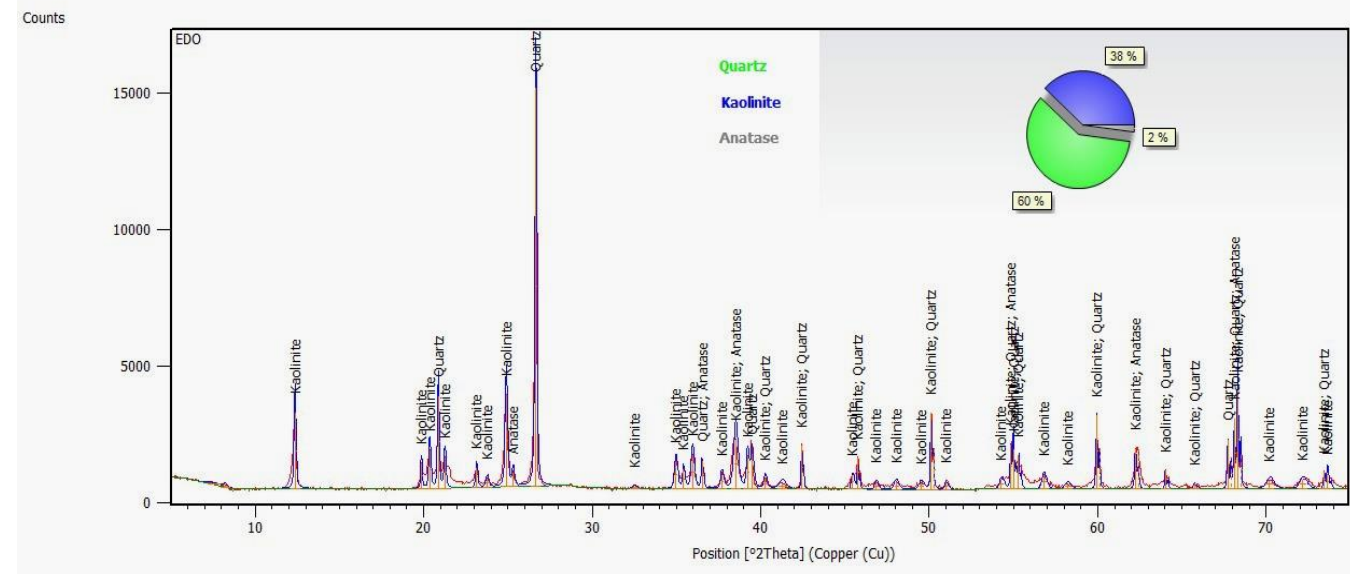

Fig. 2: XRD pattern of beneficiated Edo raw clay sample 


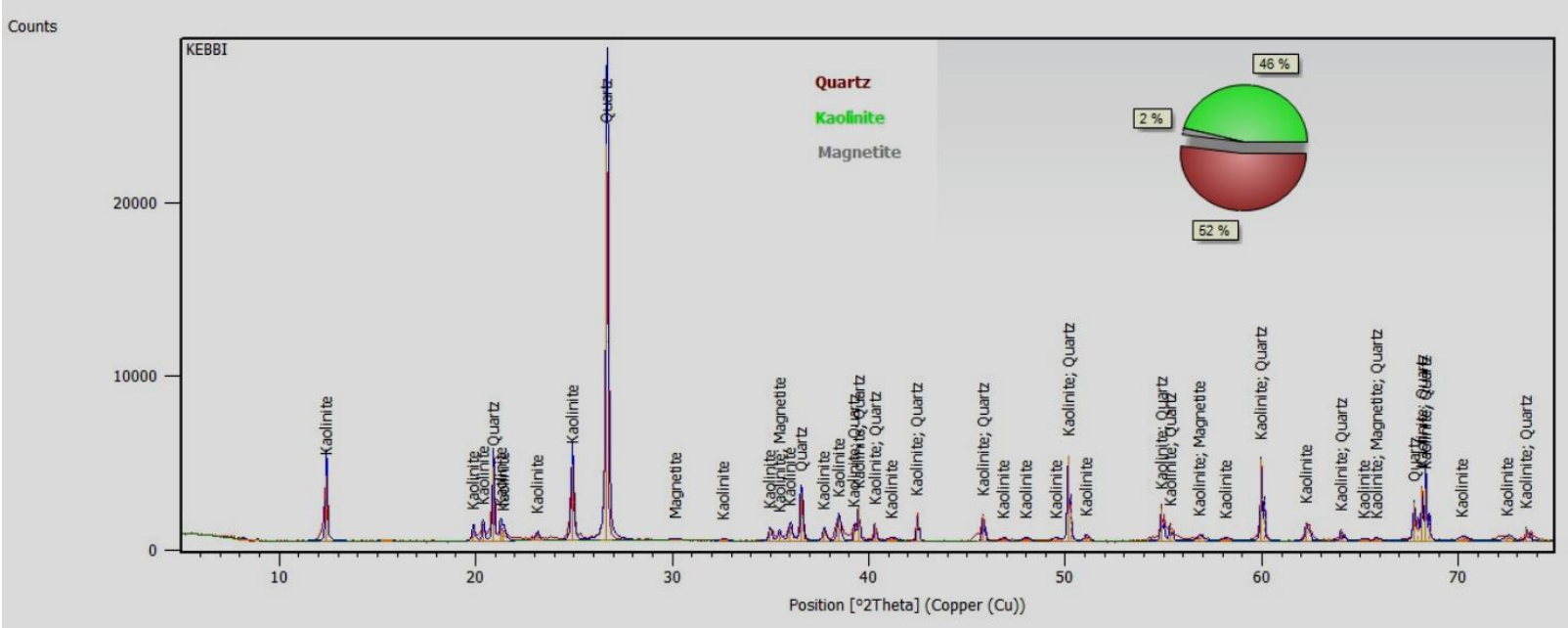

Fig. 3: XRD pattern of beneficiated Kebbi raw clay sample

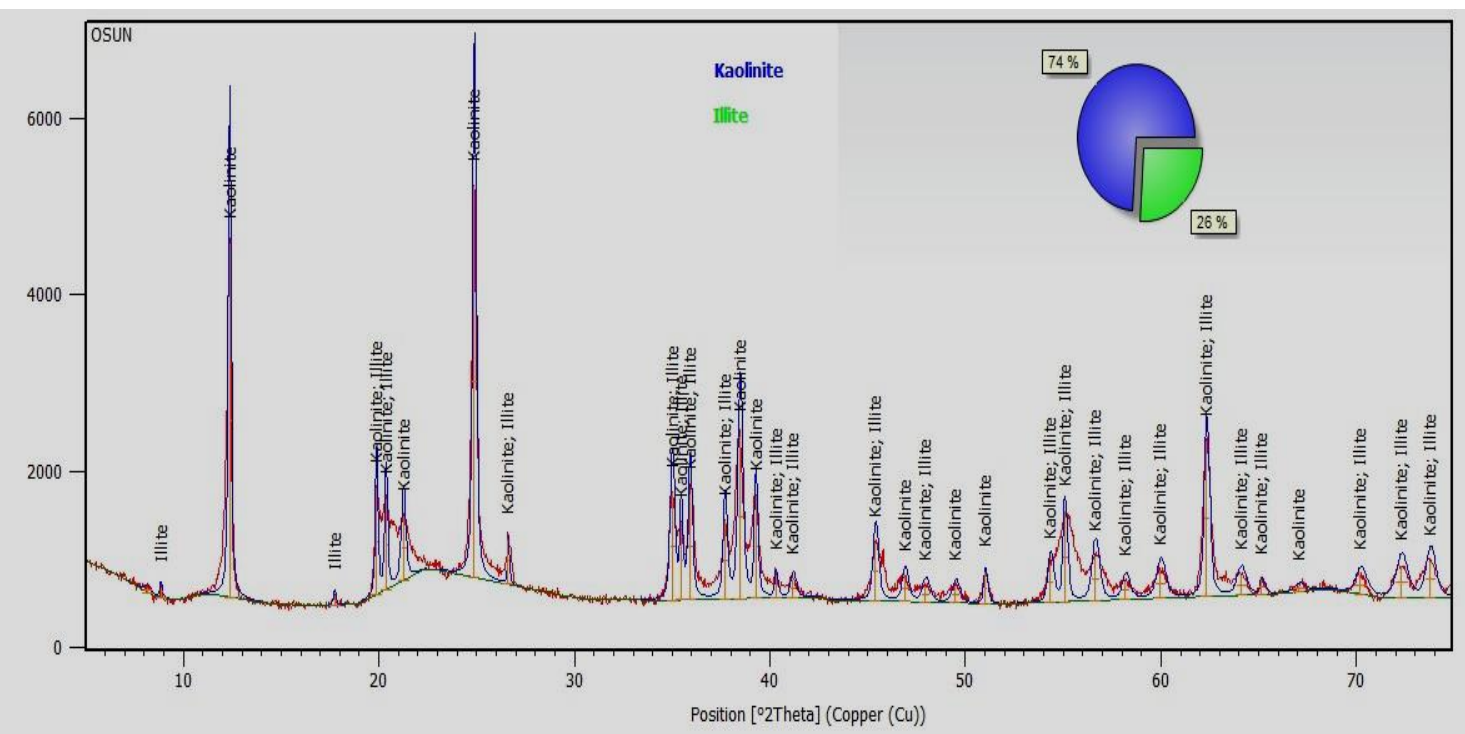

Fig. 4: XRD pattern of beneficiated Osun raw $\mathrm{Cl}$

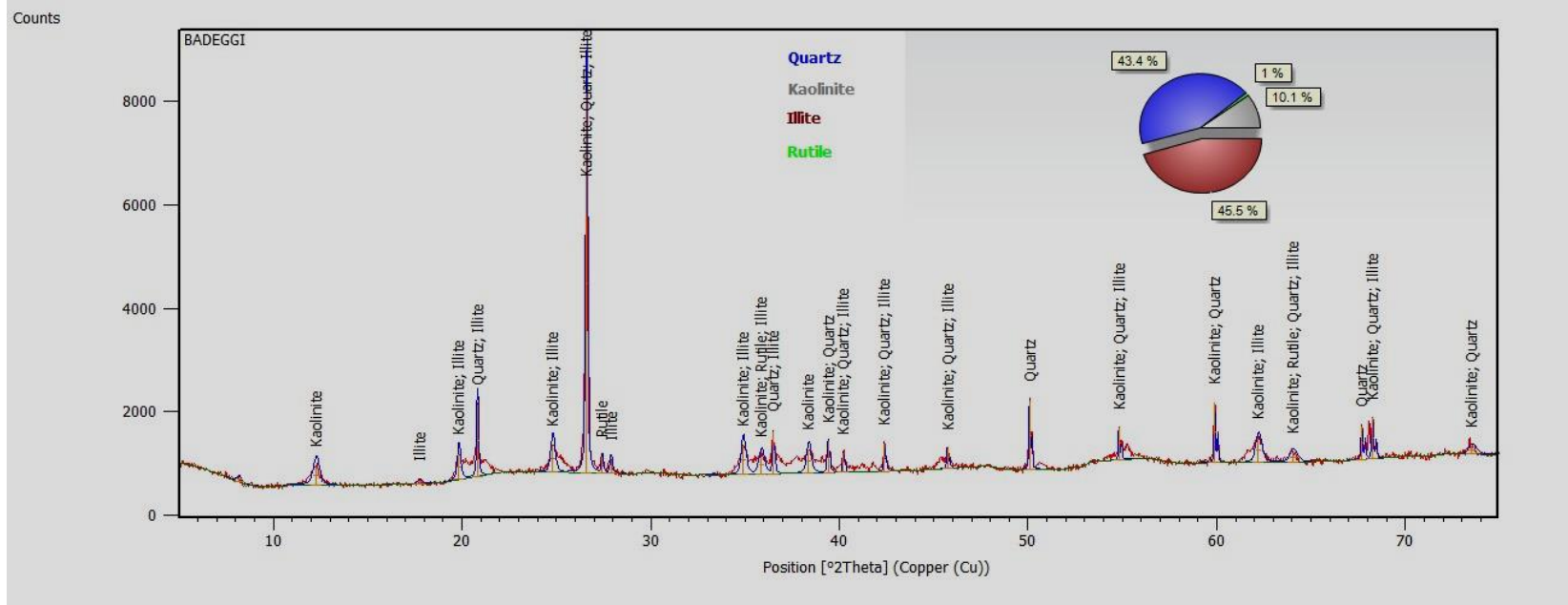

Fig. 5: XRD pattern of beneficiated Badeggi raw clay sample 


\subsubsection{SEM for Badeggi Clay Sample}

The morphologies of the four clay minerals are shown in Plate 1 - Plate 4. As can be seen, the three kaolin samples show a well-developed lamellar structure which is broken down by processing thus reducing the particle size and the volume measured with BET apparatus leading to a decreased density. The three kaolin sample shows the same behaviour. The beneficiated kaolin minerals exhibit a pseudohexagonal plate like shape which is similar to other kaolinite minerals reported by John [10]. The Badeggi ball clay as shown in Plate 4 on the other hand is much finer, from the beginning showing a very fine structure which is likely to form aggregates during processing, leading to an increased equivalent diameter and an increased density. This is what has been shown experimentally.

\subsubsection{Refractoriness Under Load of the Kaolin Samples}

The refractoriness under load test (RUL) gives an indication of the temperature at which the bricks will collapse in service conditions with similar load. However, under actual service where the bricks are heated only on one face, most of the load is carried by the relatively cooler rigid portion of the bricks. Hence the RUL, test gives only an index of the refractory quality, rather than a figure which can be used in a refractory design. Under service conditions, where the refractory used is heating from all sides such as checkers, partition walls, etc. the RUL test data is quite significant [7].

The highest temperature attained before the brick sample collapse was $t_{E}, 1348^{\circ} \mathrm{C}$ at a subsidence $-4 \%$ under a constant load of $0.2 \mathrm{~N} / \mathrm{mm}^{2}$, which was achieved from sample $C$ (Osun) kaolin sample bricks. For sample A and sample B (Edo and Kebbi) the highest temperature attained for the end of subsidence $\left(T_{E}\right)$ was $800^{\circ} \mathrm{C}$ respectively at a subsidence of $-0.8 \%$ and $-2.4 \%$ before the brick sample collapse under a constant load of $0.2 \mathrm{~N} / \mathrm{mm}^{2}$. Table 3.4 shows the Refractoriness Under Load (RUL) of various fire clay refractories made in various countries of the world [7]. Actually, the results of sample C (Osun) clay sample fall within the limits specified by the above mentioned references while that of samples B and C (Edo and Kebbi) clay falls below the specified limits of between 1200-1400 RUL standard for fire clay bricks [7]. Figure 6-8, shows the subsidence- temperature curve of Edo, Kebbi and Osun clay samples.

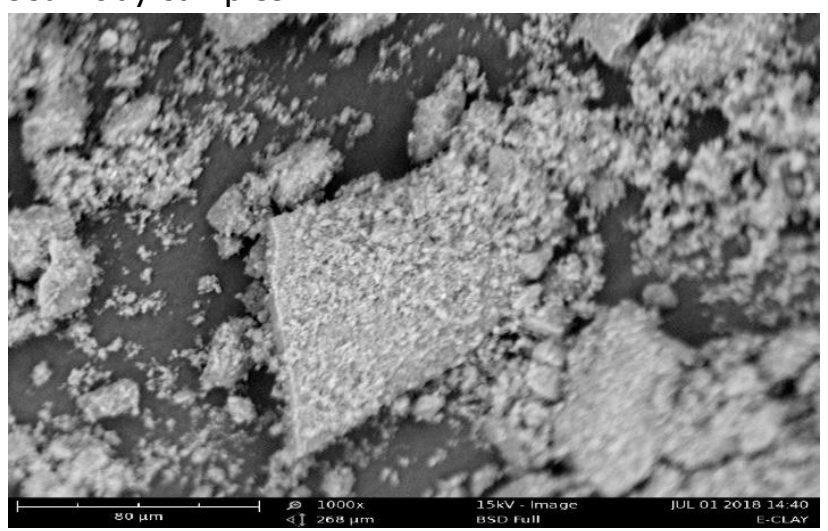

Plate 1: SEM for Edo Clay Sample

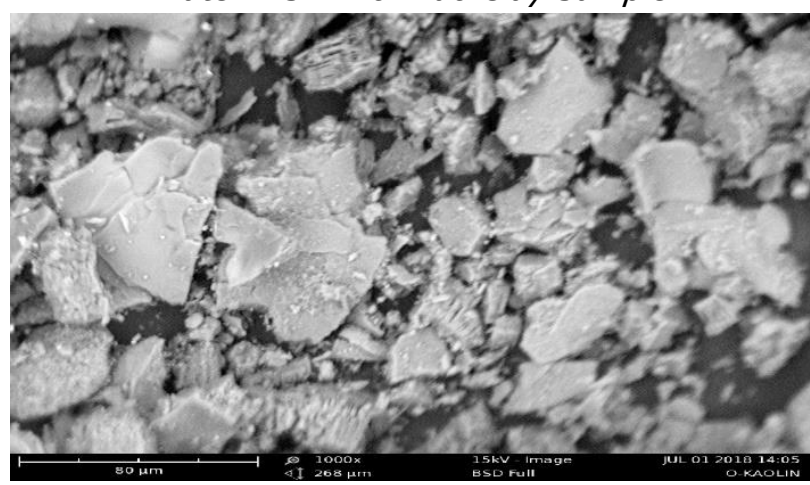

Plate 2: SEM for Kebbi Clay Sample

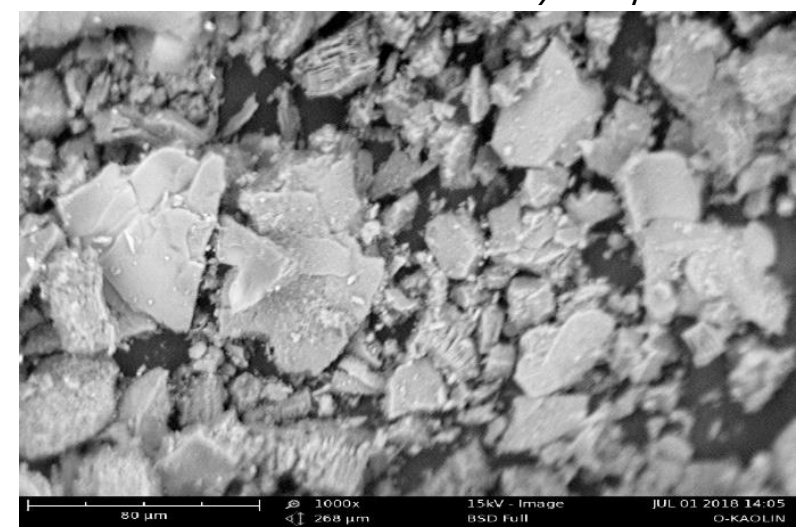

Plate 3: SEM for Osun Clay Sample

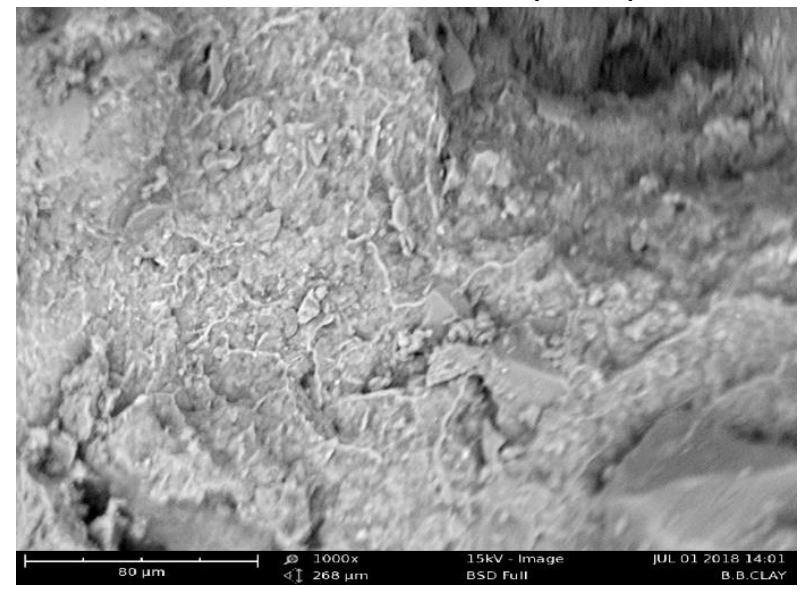

Plate 4: SEM for Badeggi Clay Sample

Vol. 38, No. 4, October 2019 
Table 5 shows the RUL of fire Clay refractories made in various countries compared to with the researched areas in Nigeria

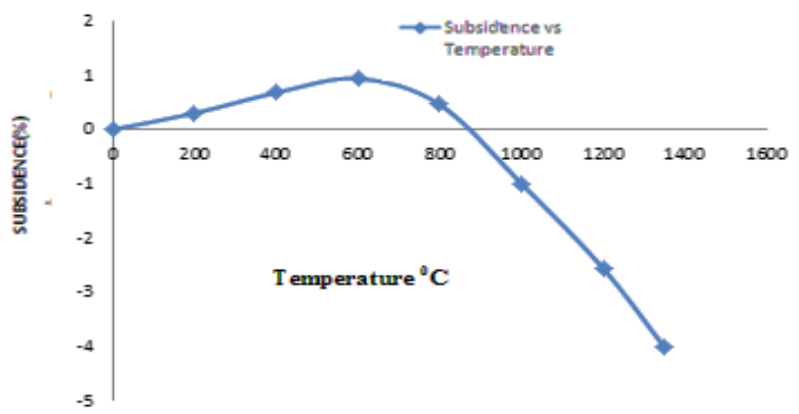

Fig. 6 : The Susbidence -Temperature curve of the Refractoriness Under Load of Edo Kaolin Clays. $\rightarrow$ Subsidence vs

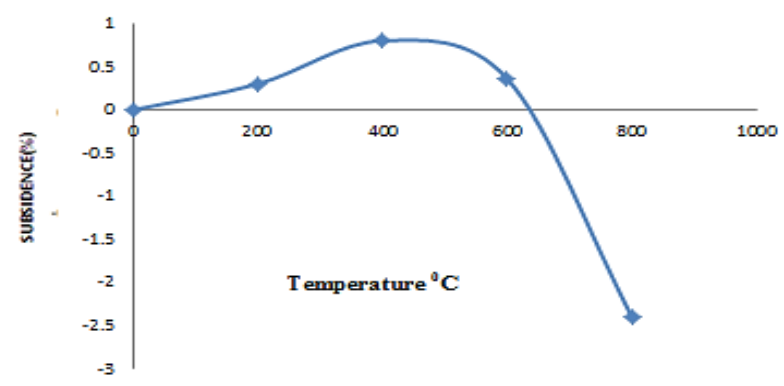

Fig. 7: The Susbidence - Temperature curve of the Refractoriness Under Load of Kebbi Kaolin Clays.

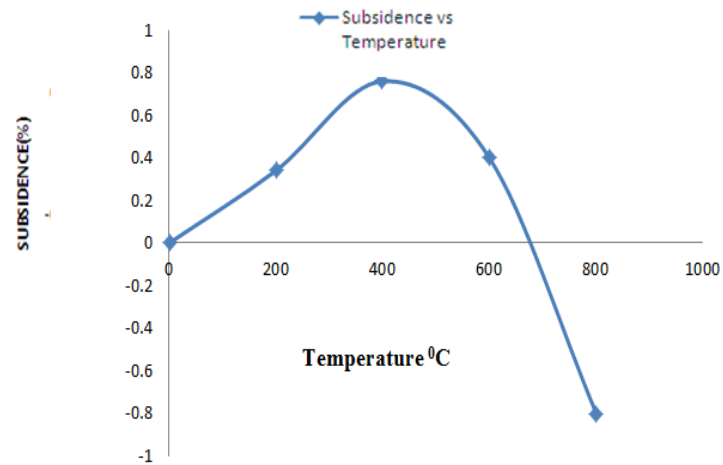

Fig 8: The Subsidence - Temperature curve of the Refractoriness Under Load of Osun Kaolin Clays.

Figure 5: RUL of fire Clay refractories made in various countries compared to with the researched areas in Nigeria

\begin{tabular}{lll}
\hline Country & & $\mathrm{RUL}\left({ }^{\circ} \mathrm{C}\right)$ \\
\hline U.K & & $1200-1400$ \\
USA & & $1150-1410$ \\
Russia & & $1305-1390$ \\
Germany & & $1230-1430$ \\
Nigeria & & \\
(i) & Edo & 800 \\
(ii) & Kebbi & 800 \\
(iii) & Osun & 1348 \\
\hline
\end{tabular}

\section{CONCLUSION}

(a) It was observed from the chemical analysis that the clay samples (A, B, C and D) revealed a fairly high proportion of silica and alumina contents. To this end it is obvious that the samples belong to the kaolinite and ball clay group. The appearance of the clay samples changes from white to light brown after firing at a temperature of $1300^{\circ} \mathrm{C}$. This was however due to the ball clay incorporated.

(b) The Bulk density value of samples A, B and C compared favourably within the normal acceptable range of between 1.7 to $2.1 \mathrm{~g} / \mathrm{cm}^{3}$ for typical fire clay.

(c) Samples A, B and C clay shows good porosity values compared with $20-30 \%$ for typical fire clay.

(d) The three clay samples show good thermal shock resistance values which compared favourably with the acceptable standard value of between $20-30^{+}$ cycles for fire clay bricks.

(e) The refractoriness of the brick produced from sample $\mathrm{C}$, based on the available furnace used, revealed that the brick was quite capable of withstanding temperatures as high as $1510^{\circ} \mathrm{C}$.

(f) Samples A,B and C clay has a specific gravity values which is within the specific gravity value of a typical fire clay brick of value 2.0-2.8.

(g) The samples produce firebricks with poor Cold Crushing Strength values, far less than the minimum requirement of $1500 \mathrm{~kg} / \mathrm{cm}^{2}$ for fire bricks.

(h)The water absorption rate for the three samples are moderately good as a brick with water absorption rate of less than $7 \%$ provide better resistance to damage by freezing. The water resistance by bricks increases with increase in pores.

(i)Moreover, from the results obtained in this investigation, based on the experimental results of the refractoriness under load test (RUL) carried out on the sample bricks, sample C (Osun) clay is capable of being used for oven and furnace lining of which temperature limit would not exceed $1400^{\circ} \mathrm{C}$. While sample A and B could be improved on through the addition of alumina oxide in varying proportion to the samples.

\section{REFERENCES}

[1]. Hassan, S.B. The Study of the Refractory Properties of some Clays. Unpublished Thesis M.Sc. (Production Engr.) The Department of 
Chemical Engineering, Ahmadu Bello Univiersity, Zaria, (1990).

[2 Kirabira, J.B., Johnson, S., and Byaruhanga, J.K. Powder Characterization of High Temperature Ceramic Raw Materials in the Lake Victoria Region" Published in KTH report series as ISRN KTH/MSE- 05/48-SE+MEK/ART (2003) pp 10 13

[3]. Mokwa, J.B \& Salihi, A. Investigation into the Refractory Properties of Badeggi Clay for Furnace Lining. Journal of Research in Engineering, 8, (1), (2011), 100-106.

[4]. Edward, H. "Effect of Spalling on Silica Brick" Research Report British Refractories Research Association (B. R. R. A) (1926), 20-25.

[5]. Olusola, E.O, Characterization of local bentonite clays for application in the foundry industry. Unpublished PhD project, Department of Mechanical Engineering, Federal University of Technology Minna. (2014), 10-15.
[6]. Chester, J.H.. Refractory Production and Properties, The Iron and Steel Institute. London. (1975). 66-69.

[7] Fayyad, M.S, Ghazi, S.A \& Suleiman, Q.A. Improvement of the Refractoriness Under Load of Fire Clay Refractory Bricks. Adv. Theor. Appl. Mech. 5 (4). (2012), 161-172.

[8] Mirzababaei, M. \& Yasrobi, S. Assessment of clay soil fabric using scanning electron microscope (SEM), In: First Sri Lankan Geotechnical Society (SLGS) International Conference on Soil and Rock Engineering, Colombo, Sri Lanka. (2007) 1-2.

[9] Shuaib-Babata, Y.L, Suitability of Nigeria Clays for Production of household Ceramic Water Filter. Unpublished PhD project, Department of Mechanical Engineering, Federal University of Technology Minna. (2014), 11, 224-231.

[10] John, B. K., Stefan J, \& Joseph, K.B. Production of firebrick refractories from kaolinitic clays of the Lake Victoria region: J. Australasian Ceram. Soc. 40, (2004) 12-19 